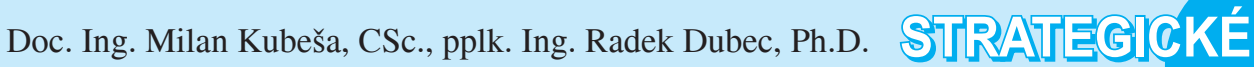 $\mathrm{K}$ teorii schopnosti ozbrojených sil
}

\section{Armed Forces Capability Theory}

\section{Abstrakt:}

Článek je zamyšlením nad problematikou schopností ozbrojených sil. Jde o fenomén, o kterém se toho již mnoho napsalo, především z hlediska potřeby její tvorby, hodnocení a rozvoje. Otázka však zní, zda jsou prijímaná praktická opatření opřena o reálný teoretický základ. Nabízí se možnost aplikovat existující teorii managementu jakosti [1] na tento specifický a frekventovaný vojenský problém. Článek je polemickou úvahou o možnosti zavedení systému managementu schopnosti do systému ř́zení ozbrojených sil.

\section{Abstract:}

The paper presents reflections over the issue of armed forces capabilities. It is a phenomenon much discussed and written earlier, namely from the point of its building, estimation and development. Nevertheless the question is whether practical experiences are backed by theory fundamentals. Now we have a chance to introduce the live theory of quality management [1] into this specific and frequented military problem. The article is a polemic consideration over possibilities of introducing capabilities management into command and control capabilities system in armed forces.

\section{Klíčová slova:}

Schopnost, jakost, schopnosti ozbrojených sil, management schopnosti, systém řízení ozbrojených sil, principy managementu schopnosti, systém managementu schopnosti.

\section{Key words:}

Capability, quality, armed forces capabilities, capability management, armed forces management system, capablity management principles, capablity management system.

Na predikované bezpečnostní hrozby by měly být státy i existující bezpečnostní instituce na všech úrovních připraveny, což ve svém důsledku znamená vynakládat potřebné finanční prostředky i v době, kdy přetrvává, a podle současných analýz ještě nějakou dobu bude působit, hospodářská recese. Rozhodující úlohu mezi výkonnými prvky bezpečnostních systémů sehrávají a zřejmě budou i v budoucnu sehrávat vybudované, moderně vybavené, vyzbrojené a na patřičné úrovni připravené ozbrojené síly. 
Rozhodující charakteristikou ozbrojených sil není ani tak jejich velikost, ale schopnost plnit zadaný úkol.

Pojem schopnost se začal používat v rozšířené míře počátkem 90. let minulého století, kdy nastal požadavek na hledání nových přístupů pro plánování rozvoje ozbrojených sil. V těchto letech se začala využívat tzv. metoda plánování pomocí schopností. Od této doby se pojem schopnost začíná v rozšířené míře používat ve všech strategických vojenských dokumentech i v běžné praxi ozbrojených sil. Česká republika jako člen NATO byla rovněž do tohoto procesu plně integrována a pojem schopnost se od této doby objevuje v řadě dokumentů, které stanovují činnost a směry rozvoje ozbrojených sil.

\section{Co je možné chápat pod pojmem „schopnost" ?}

Pod pojmem ,schopnost“ si lze představit ledacos. V obecné rovině ji lze chápat jako způsobilost určitého produktu nebo služby k užití nebo to, co požaduje po určitém produktu nebo službě její uživatel, zákazník atd. [1] Z hlediska ozbrojených sil lze schopnost chápat jako způsobilost k vedení bojové, ale také nebojové činnosti, tedy k užití, jelikož jejich smyslem je právě toto použití. Pokud jsou vytyčeny určité požadavky na ozbrojené síly, např. aby byly schopny překonávat vodní překážky nebo aby byly přepravitelné vzduchem, a tyto jsou naplněny (požadavky se shodují s jejími vlastnostmi), pak lze konstatovat, že ozbrojené síly resp. jejich konkrétní jednotky mají schopnost překonávat vodní překážky a jsou přepravitelné vzduchem. Jsou to jejich schopnosti. Pro národní ozbrojené síly je zákazníkem daný stát. Pro mnohonárodní operační uskupení může být zákazníkem aliance či koalice států, které se na vytváření uskupení podílejí. Tito zákazníci považují to, že ozbrojené síly, tvořící operační uskupení, oplývají takovými vlastnostmi jako je umění překonávat vodní překážky, jsou přepravitelné vzduchem atd. za jejich schopnosti. Výstižnou definicí schopnosti by mohla být následující charakteristika:

Schopnost je stupeň splnění požadavků souborem inherentních charakteristik. (Nenadál, 2008) [2]

Česká technická norma chápe schopnost jako zpo̊sobilost (jak se pro účely české technické normy překládá identický anglický termín) organizace, systému nebo procesu realizovat produkt, který splní na něj kladené požadavky. [3]

Chápání pojmu „schopnost“ je v podmínkách ozbrojených sil objasněno v základní vnitřní normě, tj. v rozkaze ministra obrany. V tomto dokumentu je schopnost definována jako soubor nezbytných vlastností jednotlivce, organizačního celku, úkolového uskupení nebo charakteristik systému (např. zbraňového) k vytvoření požadovaného efektu (např. splnění bojového úkolu, dosažení cíle). Základním nositelem schopností v rezortu obrany je organizační celek, jehož schopnosti vycházejí z tabulek počtů a jsou definovány úrovní jeho připravenosti k činnosti. [4]

\section{Vztah pojmů ,schopnost" a ,jakost"}

Věc, systém, organizace se projevuje vzhledem ke svému okolí, ale i směrem ke svým vnitřním prvkům určitými funkcemi, jejichž projevem může být určitá činnost - schopnost 
plnit určité úkoly. Pojem „schopnost“ sám o sobě je nepředstavitelný, nesmyslný, resp. prázdný. Je třeba tento pojem spojit s činností, s věcí, systémem, organizací. Schopnost plnit úkol, funkci, ovlivňovat, omezovat, rozvíjet atd. znamená provádět určitou činnost - plnit konkrétní úkol. Lze konstatovat, že schopnost je způsobilost plnit úkol, schopnost realizovat činnost. Z hlediska ozbrojených sil jde v prvé řadě o schopnost plnit úkoly obrany státu před napadením - schopnost bránit stát. Tato schopnost bude kvalitnější, pokud budou ozbrojené síly lépe vyzbrojeny, vybaveny, vycvičeny, podporovány obyvatelstvem a dalšími aktéry, pokud budou mít kvalitnější velení, kvalitnější spojence atd. Jelikož kvalita je synonymem pojmu ,jakost“, je možné konstatovat, že schopnost ozbrojených sil bránit stát může mít různou kvalitu - různou jakost. Z tohoto hlediska lze pojem schopnost (schopnost ozbrojených sil bránit stát) ztotožnit s kvalitou plnění úkolu, jehož podstatou a ústředním úkolem je obrana státu. Kvalitnější obrana státu ozbrojenými silami mj. znamená disponovat schopnějšími ozbrojenými silami.

\section{Schopnost jako měřitelná veličina}

Ozbrojené síly sice mají určité schopnosti, např. vést bojovou činnost v urbanizovaném prostoru, v zalesněném terénu či poušti, ale tyto lze kategorizovat do více stupňů. Jednotka typu A (na lehkých a rychlých vozidlech) má výbornou schopnost vést bojovou činnost v urbanizovaném prostoru, jednotka typu B (na středních obrněných transportérech) má dobrou schopnost bojovat v tomto prostoru, a konečně tanková jednotka tuto schopnost má velmi omezenou pro svou mimořádnou zranitelnost. Schopnost ozbrojených sil resp. jejich určitých součástí je měřitelná a může zahrnovat více stupňů (úrovní). Měřitelnost schopnosti je možné provádět celou řadou různých metod, postupů a s využitím hodnotových tabulek a stanovených kritérií a jejich parametrů.

Některé jednotky mají vysokou schopnost vést bojovou činnost v urbanizovaném prostoru, jiné mají tuto schopnost na střední úrovni a některé tuto schopnost sice mají, ale na nízké úrovni. Bezesporu jsou jednotky, které tuto schopnost vůbec nemají. Stupně schopnosti ozbrojených sil lze chápat i z pohledu připravenosti plnit daný úkol. Jednotka typu A může být výborně vycvičena pro boj ve městě, ale jiná jednotka typu A oplývá nízkou úrovní této schopnosti z důvodu podcenění výcviku.

\section{Schopnost jako uspokojování požadavků (externích) zákazníků}

Požadavky jsou obvykle dány kombinací požadavků externích zákazníků (tzn. jejich potřeb a očekávání), dalších zainteresovaných stran, a také zákonů a směrnic. [1] V případě ozbrojených sil je obvyklé, že vláda daného státu si klade požadavky k zajištění vlastní obrany ve smyslu vysoké bojové připravenosti a pohotovosti určených sil, k zajištění posílení záchranného systému státu pro případ přírodních katastrof a průmyslových (ekologických) havárií, ke stř̌ežení životně důležitých center státu k obraně před teroristy apod. V případě bezpečnostní instituce např. NATO si její nejvyšší vedení klade požadavky na vyčlenění takových vojenských sil členských států, aby schopnosti odpovídaly potřebám řešit konkrétní krizovou situaci. V př́ípadě řešení krizové situace s převažujícím charakterem humanitární pomoci určitému regionu může NATO vznést 
na členské státy požadavek na vytvoření operačního uskupení v takovém složení, aby schopnosti vyčleněných sil odpovídaly dané potřebě a danému charakteru úkolu (humanitární operace se vyznačuje jinými inherentními charakteristikami nežli operace bojová). [5] K inherentním charakteristikám humanitární operace patř́ zdravotnická podpora, ubytovací služby, potravinová pomoc, hygienicko-epidemiologické zabezpečení, dopravní kapacity apod. Státy pak podle svých možností tyto síly (vojenské polní nemocnice, jednotky ke střežení objektů a udržování pořádku, chemické, ženijní, spojovací a dopravní jednotky) vyčleňují a nabízejí jejich schopnosti plnit úkoly v této humanitární operaci.

Hovořit o schopnosti bez vztahu k zákazníkovi a procesu, pro který je schopnost určena, není myslitelné. Každá schopnost produktu či služby musí být spojována jak se zákazníkem, tak i s procesem jejího dosahování, nebot tato vazba je neoddělitelná. Vyrobený produkt se svou hlavní schopností je určen pro poskytování služeb a naplňování potřeb uživatele. Proto je nezbytné si podrobněji charakterizovat pojem zákazníka.

Zákazník je subjekt, kterému jsou výsledky procesu určeny. Subjektem může být osoba, organizace nebo následující proces. Zákazníky členíme v obecné rovině na interní a externí. Interním zákazníkem je organizační prvek nebo složka v rámci dané organizace, externím zákazníkem je pak v př́ípadě ozbrojených sil veřejnost ČR a zainteresované strany, např. parlament, vláda, NATO, EU, OSN. Interní zákazník výsledky jiného procesu využívá jako vstupy do procesu, který sám provádí. Zákazník je tedy tzv. odběratel nebo uživatel výstupu procesu.

Proces pak chápeme jako sled činností, který má vždy jasně vymezený začátek, probíhající činnosti, konec a rozhraní - návaznost na ostatní procesy. Výstup z předcházejícího procesu musí být shodný se vstupem do následujícího procesu. Je tedy nutné detailně analyzovat reálné výstupy z procesu s výstupy požadovanými. [6]

Z oblasti ozbrojených sil lze uvést, že uživatelem samopalu je voják, který využívá schopnosti této zbraně k vlastní obraně a k ničení živé síly protivníka, uživatelem mechanizované jednotky je nadřízené velitelství, které využívá bojové i jiné schopnosti jednotky při plnění úkolu od nadřízeného stupně, uživatelem ozbrojených sil je stát, který prostřednictvím vlády a orgánu strategického velitelství využívá jejich schopnosti k obraně státu a k jiným určeným úkolům a nap̌r. uživatelem vytvořeného operačního uskupení v rámci strategického uskupení NATO je strategické velitelství NATO.

\section{Znaky schopností}

U každého produktu lze identifikovat znaky schopností, které lze rozdělit na znaky kvantitativní (tj. měřitelné - rozměrově, obsahově, výkonově apod.) a znaky kvalitativní - atributy, které nelze vyjádřit číselnou hodnotou, ale jsou pro zákazníka důležité (vůně, př́ijemná atmosféra, chut' atd.). [1] $\mathrm{V}$ př́ípadě ozbrojených sil patří ke kvantitativním znakům schopností vojenské jednotky - počet osob, zbraní, zbraňových kompletů, bojové a dopravní techniky, množství zásob munice, pohonných hmot a proviantu, náhradních dílů k opravám atd. Kvalitativními znaky schopností vojenské jednotky mohou být např. celková připravenost (vycvičenost) jednotky k plnění úkolu, zkušenosti velitelů a štábních pracovníků, stav výzbroje a techniky z hlediska její funkčnosti, stupeň pohotovosti k zasazení do mise, kvalita systému spojení, zásobování, oprav atd. Tyto 
znaky se zpravidla vyjadřují pomocí DOTMLPFI (Doctrine, Organization, Training, Materiel, Leadership, Personnel, Facilities, Interoperability). Znaky schopností jsou u různých entit velmi rozmanité a vypovídají o charakteru těchto entit. U zbraňových systémů tvoří skupiny znaků schopnosti technické parametry, provozní spolehlivost, jednoduchost obsluhy, ekologický standard, apod., u bojové vojenské jednotky znaky schopností vypovídají o bojové síle, manévrovosti, odolnosti před účinky zbraní protivníka, spolehlivosti systému velení a řízení, dopravně-kapacitní parametry atd.

\section{Management schopnosti jako nedílná součást celkového systému ř́zení ozbrojených sil}

Základ pro existenci a fungování systému obrany státu je položen v systému obranného plánování státu. Nedílnou součástí celkového systému řízení ozbrojených sil by měl být systém managementu schopnosti, který lze charakterizovat jako soubor vzájemně souvisejících prvků (procesy, osoby, materiály, informace i zařízení), který má garan-

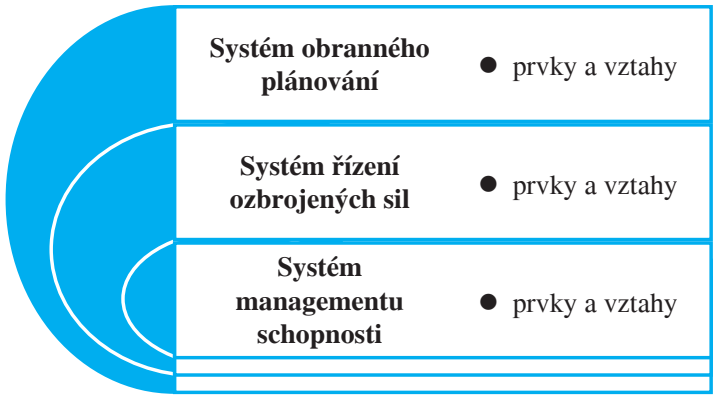

Obr. 1: Vzájemný vztah systémů tovat maximalizaci spokojenosti zainteresovaných stran při minimální spotřebě zdrojů.

Na obr. 1 je znázorněn vztah výše uvedených pojmů. Jde tedy o to, aby zákazníci (stát, vláda, občané, orgány NATO nebo EU) ozbrojeným silám důvěřovali, aby měli na ně spolehnutí, a to především $z$ hlediska jejich požadované schopnosti bránit stát a podílet se na společných aliančních úkolech.

V rámci celkového systému řízení ozbrojených sil probíhá proces, který začíná politickým rozhodnutím vrcholných státních představitelů o potřebě obrany a zajišt’ování bezpečnosti státu ve formě projednané a schválené bezpečnostní a obranné strategie státu. Pokračuje tvorbou vize, strategie a koncepce výstavby ozbrojených sil a dalších funkčních a institucionálních koncepcí, střednědobých a krátkodobých plánů, které se prakticky postupně realizují konkrétními rozvojovými projekty a procesy. [7]

Výstupem jsou vybavené, vyzbrojené a připravené útvary, zařízení a velitelství splňující charakteristiky v oblastech vyjádřených zkratkou DOTMLPFI, ale které se prověřují a dále rozvíjejí na základě nejnovějších poznatků vědy a získaných zkušeností z praktických zasazení. Prověřování dosažených schopností může být formou CREVAL, TACEVAL, kontrolního cvičení atd. Ve své podstatě jde o dosažení co nejkvalitnějších schopností ozbrojených sil k plnění zadaných úkolů. A právě činnost managementu, jež sleduje vše kolem úrovně (stupně) schopností ozbrojených sil, lze pojmout jako management schopnosti. Může se rozčlenit na jednotlivé dílčí etapy (obr. 2).

V etapě plánování schopností je část managementu schopnosti realizovaná v rámci dlouhodobého (strategického) plánování, zaměřena na tvorbu vizí, strategií rozvoje, koncepcí, plánů (střednědobých a krátkodobých), jež vycházejí z vizí, koncepcí a plánů 
vyššího řádu. Tato etapa je realizována v rámci strategického řízení organizace. V podmínkách ozbrojených sil se vychází z politického zadání vrcholných představitelů státu, které vrcholový management rezortu obrany, na základě požadavků a závazků NATO a EU, v součinnosti s jinými rezorty rozpracovává do strategických dokumentů, kde se především řeší složení a struktura ozbrojených sil, stanovení cílů rozvoje schopností ozbrojených sil jako celku a jejich jednotlivých součástí, zdroje k dosažení cílů rozvoje schopností a způsob dosažení cílů rozvoje těchto schopností zpravidla zpracovaný ve formě strategie rozvoje nebo koncepce rozvoje. [5]

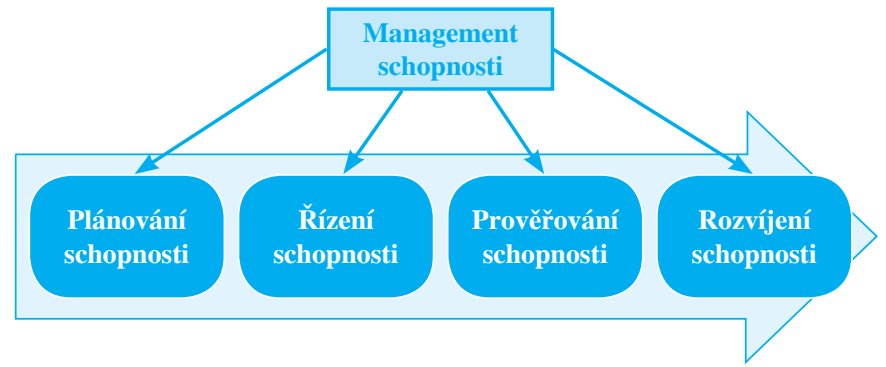

Zdroj: Upraveno podle [1]

Obr 2: Management schopnosti

Proces dlouhodobého (strategického) plánování v podmínkách rezortu obrany lze jednoznačně charakterizovat jako rozvojové strategické plánování, které má své zdroje, regulátory řízení, politické zadání a mezinárodní závazky, ke kterým se ČR přihlásila, at' již v rámci mezinárodní organizace, nebo samostatně. Základními zdroji do každého dlouhodobého (strategického) plánování jsou lidé, materiál, finance, informace a čas. Ne všechny zdroje jsou pro organizaci omezeny, a tak se v plánech uvádějí především ty zdroje, které jsou limitující. V podmínkách rezortu obrany to mohou byt finanční zdroje, lidské zdroje, ale i materiální zdroje. Jedním ze základních plánovacích dokumentů v rezortu obrany je dlouhodobý výhled. Vyjadřuje dlouhodobý záměr rozvoje, udržení nebo utlumení klíčových schopností vycházející ze soudobé Obranné strategie České republiky. U dlouhodobého výhledu, který je nutné chápat jako dlouhodobý plán, je potřebné co nejpřesnější určení zdrojů, ze kterých lze predikovat nároky na budoucí schopnosti. Veškeré schopnosti musí být celkově v souladu s posláním organizace, a zároveň z poslání musí vycházet. [8] Úroveň jednotlivých schopností může být v závislosti na dostupnosti potřebných zdrojů a čase potřebném k dosažení schopnosti parametricky omezena, je-li riziko s tím spojené akceptovatelné z hlediska poslání a plnění úkolů rezortu obrany. [4]

V etapě řízení schopnosti je část managementu schopnosti zaměřená na plnění požadavků na schopnosti. Jde o postupnou realizaci opatření rozpracovaných ve strategii rozvoje (dlouhodobém výhledu), koncepcích a plánech. Výsledkem etapy jsou fungující ozbrojené síly, které dosáhly plánovaných schopností. V současné době standardní proces řízení schopnosti není v rezortu obrany normativně stanoven, není přesně popsán, nemá zcela optimalizovaný průběh a sledy jednotlivých subprocesů a činností, které jsou nezbytné pro naplnění tohoto procesu, a tím dosažení nebo udržení požadované schopnosti.

V etapě prověřování schopnosti je část managementu zaměřená na kontroling. Cílem této etapy je prokazování schopnosti ozbrojených sil, porovnávání požadovaných 
a skutečně dosažených schopností a přijímání opatření k nápravě. V rámci této etapy jsou využívány postupy formou CREVAL, TACEVAL, kontrolního cvičení atd.

V etapě rozvíjení schopnosti je část managementu zaměřená na další zvyšování schopnosti ozbrojených sil na základě požadavků vyplývajících ze změn bezpečnostního prostředí a z nových požadavků na schopnosti ze strany vnějších partnerů či institucí. V případě České republiky mohou nové požadavky na schopnosti ozbrojených sil přicházet z NATO nebo EU.

\section{Ideální schopnost je prakticky nedosažitelná}

Je potřebné zdůraznit, že schopnost uspokojovat požadavky uživatelů není realizována pouhým užitím produktu nebo poskytnutím služby, ale vzniká v rámci celého reprodukčního, resp. modernizačního procesu. Výsledná schopnost (totální - ideální schopnost $=100 \%$ plnění požadavků uživatelů) může být v tomto procesu snižována nedokonalým systémem tvorby schopnosti (např. výcvikem, výcvikovým zařízením, logistickým zabezpečením a jeho expedicí, plánováním přípravy jednotky, jejím taktickým předurčením atd.). Zkušenosti ukazují, že výsledná (ideální) schopnost je pouze asi z 50\% tohoto ideálu. [1] Míra přiblížení k ideální schopnosti je závislá na dokonalosti systému tvorby schopností, tj. managementu schopnosti. Při aplikaci obecných zkušeností z oblasti tvorby schopností lze soudit, že celý proces výstavby a př́ípravy ozbrojených sil má obdobně 50\% schopnost ideální (totální) schopnosti. V současných podmínkách hospodářské recese to může být ještě méně.

Důležitým závěrem k hodnocení dosažené míry (úrovně) klíčové schopnosti ozbrojených sil - schopnosti k obraně státu - je to, že tato schopnost je tvořena ve všech fázích celého procesu managementu schopnosti. Schopnosti pak vyjadřují způsobilost ozbrojených sil efektivně působit v krizových situacích a válečných konfliktech a jsou podmíněny dostatkem připraveného personálu, odpovídající organizační strukturou, kvalitou výzbroje a techniky, adekvátními zásobami, úrovní výcviku a všestranného zabezpečení a dalšími faktory.

Stát jako uživatel ozbrojených sil musí dbát o to, aby přijaté politické rozhodnutí bylo reálné, aby přijatá koncepce výstavby byla realizovatelná, aby byly plány a směrnice k výstavbě postaveny na základě skutečných a možných potřeb, aby výstavba jednotlivých útvarů a jejich naplněnost odpovídala potřebám a konečně, aby vzdělávání a výcvik probíhal v duchu nejnovějších zkušeností a aktuálních výsledků vědy a výzkumu. Nákup nekvalitní nebo nevhodné vojenské techniky, naplněnost útvarů neodborně připraveným personálem a nízká sladěnost vojsk, jakož i nízká úroveň vzdělávání velitelského sboru snižuje stupeň (úroveň) cílové (výsledné) schopnosti. Jde o to, aby k těmto zbytečným ztrátám nedocházelo.

\section{Schopnost jako kritický faktor úspěšnosti organizace}

Mezi kritické faktory úspěšnosti jakékoliv organizace jsou obvykle uváděny schopnost, náklady, čas a znalosti zaměstnanců. [1] Náklady zde reprezentují snahu splnit požadavky na schopnosti s co nejmenší spotřebou zdrojů.

Na tomto místě není třeba dokazovat, že se těchto schopností může dosáhnout za podmínky dostatečného počtu skutečně odborně způsobilých a vhodně motivovaných 


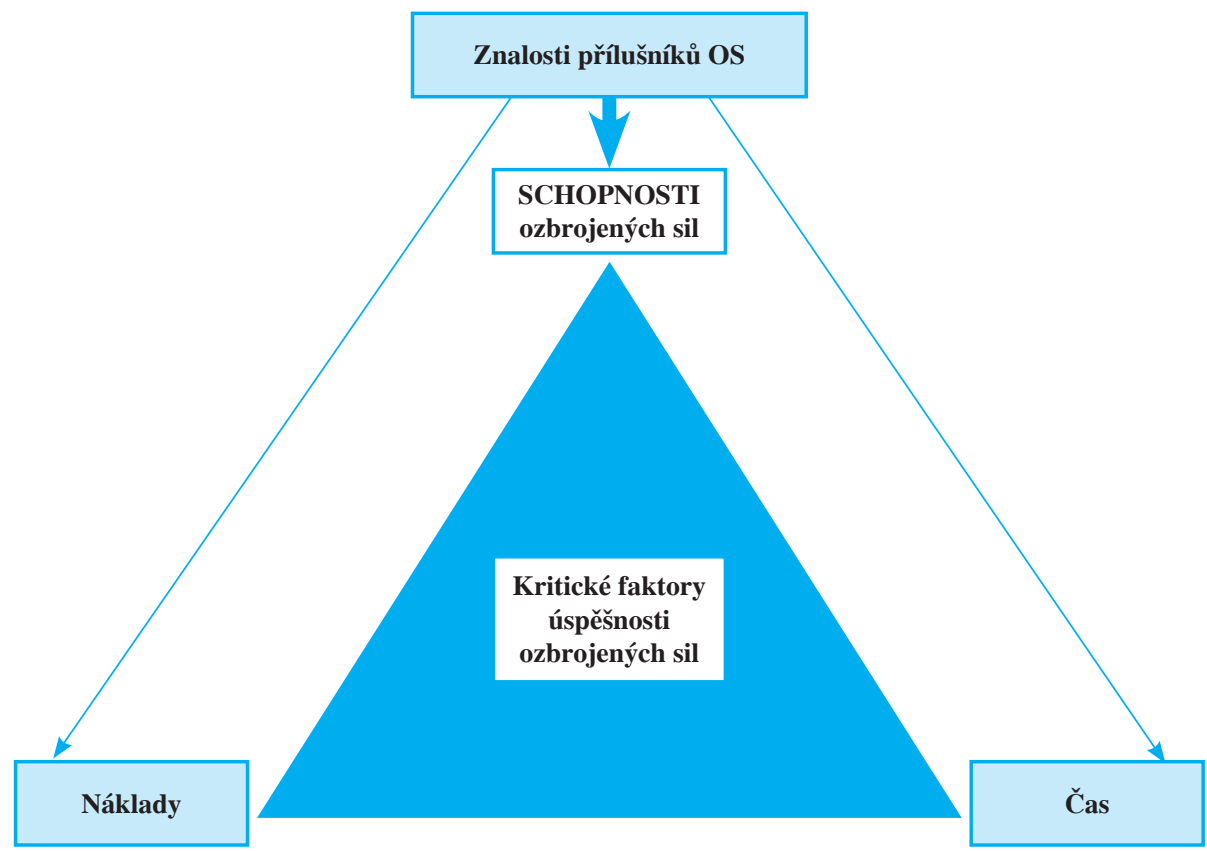

Zdroj: Upraveno podle [1]

Obr. 3: Kritické faktory úspěšnosti ozbrojených sil

zaměstnanců. Podle některých studií bude v první polovině 21. století rozvoj organizací až z $90 \%$ ovlivňován právě úrovní znalostí lidí. Tyto obecné zásady lze aplikovat na ozbrojené síly (viz obr. 3). Při aplikaci těchto obecných zásad na ozbrojené síly lze jednoznačně konstatovat, že smysl existence resp. úspěšnost ozbrojených sil vychází z těchto faktorů. Stát jako zákazník očekává a potřebuje, aby ozbrojené síly (OS) byly co nejrychleji a s minimálními náklady připraveny $\mathrm{k}$ obraně státu. Tohoto stavu lze dosáhnout s dostatečně připravenými veliteli a štábními pracovníky.

\section{Principy managementu schopnosti}

Aby byl jakýkoliv systém managementu schopnosti pro organizaci př́nosem, měl by být postaven na pevných základech. Těmito základy jsou i určité principy - základní pravidla, resp. výchozí myšlenky, které se vyplatí k zajištění úspěšnosti organizace dodržovat.

Mezi základní principy pro efektivní systémy managementu schopnosti organizací patří např. podle [1]: zaměření na zákazníka, vůdcovství, zapojení zaměstnanců, učení se, flexibilita, procesní př́stup, systémový př́stup k managementu, neustálé zlepšování, management na základě faktů, vzájemně prospěšné vazby s dodavateli a společenská odpovědnost.

Tyto principy lze bez velkých problémů aplikovat na problematiku tvorby, rozvíjení a hodnocení ozbrojených sil. Z hlediska možné představy jsou uvedena možná opatření na dvou důležitých principech. 
Princip zaměření na zákazníka je dostatečně srozumitelný většině manažerů. Problémem však někdy je otázka, co konkrétního by se mělo k naplnění tohoto principu dělat. Výčet nejdůležitějších procesů a činností je široký a pro podmínky ozbrojených sil lze uvést několik př́kladů:

a) Definování toho, kdo je pro organizaci, tedy pro ozbrojené síly, zákazníkem. Tím hlavním zákazníkem je stát, což je pochopitelné. Dalšími zákazníky mohou být $\mathrm{v}$ př́ípadě vyčleňování kontingentu do mnohonárodních operačních uskupení velitelství NATO (EU), resp. určené operační velitelství těchto institucí. Každá vojenská jednotka, každý útvar či instituce mají svého nadřízeného, kterého lze také považovat za zákazníka. [9]

b) Systematické zkoumání a poznání požadavků na schopnosti OS přicházejících od uvedených zákazníků. V podmínkách OS jde o tvorbu operačních koncepcí, zevšeobecňování zkušeností, využívání systému LL (Lessons Learned), výsledků vědecké práce apod. [10]

c) Definování cílů organizace tak, aby byly v souladu s požadavky zákazníků. Z hlediska ozbrojených sil státu jsou tyto cíle stanoveny ve vojensko-strategických dokumentech a doktrínách daného státu, resp. koalice (aliance).

d) Systematickou komunikací požadavků zákazníků v organizaci, vedenou a podporovanou vrcholovým vedením tak, aby byly požadavky srozumitelné všem zaměstnancům. Z hlediska OS jde o dosti obvyklý problém, kdy se pod pojmem komunikace chápe často jen proud informací shora dolů (ve formě rozkazů a nařízení), což může mít za následek dostatečné nepochopení požadavků nadřízených. Proto i zpětná vazba a možnost diskuze je na místě.

e) Rychlé a efektivní plnění požadavků zákazníků - tedy pružnou reakci v podobě rychlého poskytnutí žádané služby, produktu při co nejmenší spotřebě zdrojů. V OS jde o pružné zavádění nových zbraňových systémů splňujících požadavky efektivní bojové činnosti vojsk, rychlé zvládnutí a využívání těchto systémů veliteli a vojáky při reálných zasazeních v duchu použitelných vojenských doktrín a manuálů. [9]

f) Systematické měření spokojenosti, nejlépe formou pravidelných zkoumání názorů. V OS se toto opatření zpravidla provádí v rámci pracovních seminářů, národních a mezinárodních konferencí, s cílem vyměňovat si názory na aktuální otázky výstavby, rozvoje a použití OS v operacích. Provádí se i cvičení se štáby i s vojsky s cílem ověřovat schopnosti velitelů, štábů a vojsk umět plánovat a vést operace, a tím ověřovat platnost vojenských doktrín.

g) Rozvoj vztahů se zákazníky, což v podmínkách OS znamená být neustále v kontaktu s politickou reprezentací státu, vojenským velením NATO (EU) a $\mathrm{v}$ obecné rovině s nadřízenými velitelstvími v rámci struktury ozbrojených sil.

- Princip vůdcovství je jedním z klíčových pro fungující systémy managementu schopnosti. Podstata principu spočívá ve výroku, že „کrídící pracovníci musí být pozitivním př́kladem ostatním zaměstnancům organizace svým chováním, postoji a jednáním, které garantuje stálost účelu organizace a její strategické směřování“" Tento princip od velitelů a rrídících pracovníků v OS může být kromě jiného prosazován následujícími aktivitami: 
a) Systematické zkoumání a poznání potřeb a očekávání všech zainteresovaných stran (tím tento princip navazuje na předchozí zásady). Pro OS z toho vyplývá, že musí reagovat na nové aspekty vývoje bezpečnostního prostředí, musí být neustále ve střehu z hlediska potřeb svého hlavního zákazníka - státu, NATO (EU), musí přispívat k řešení vzniklých krizí, nesmí dopustit stagnaci v inovaci výzbroje, zaostávání v obranném výzkumu, v rozvoji vojenských doktrín a hlavně v prŕípravě velitelů, štábů a vojsk k předpokládaným činnostem.

b) Definování jasného a na zájmy zainteresovaných stran orientovaného poslání, vize, strategie a koncepcí. V OS jde o přesvědčení lidí a jejich motivaci k dosažení profesionálních schopností, čehož se může dosáhnout reálně zpracovaným dlouhodobým výhledem rozvoje, reálně zpracovanými střednědobými plány činnosti, promyšlenými reorganizacemi, prosazováním koncepčního myšlení s využitím analytických a prognostických technik a predikcí při tvorbě a rozvoji operačních, institucionálních a funkčních koncepcí rozvoje OS atd.

c) Stanovení takových strategických cílů organizace, jež budou ve všech oblastech (včetně ekologických otázek) výzvou budoucnosti.

Uvedené příklady dávají dostatek podnětů k dosažení představy o možnosti aplikovat i další výše uvedené principy na podmínky OS a jejich schopnosti.

\section{Závěr}

Teorie schopnosti není doposud v potřebné míře vytvořena. Existující studie a odborné texty řešící tuto problematiku jsou pouze zevšeobecněné zkušenosti vojenské praxe postrádající teoretický základ.

Existující teorie managementu jakosti (kvality) je plně aplikovatelná v oblasti tvorby, hodnocení a rozvoje schopnosti OS. Proces tvorby jejich schopností (schopností OS bránit stát a plnit spojenecké závazky) je složen z dílčích procesů, které na sebe navazují nebo běží souběžně a jejichž výsledkem jsou OS, které disponují určitou úrovní schopností bránit stát a schopností podílet se na aliančních úkolech.

Dílčími procesy jsou: tvorba obranné strategie státu, tvorba teorie vojenského umění a doktrín, které obsahují návody, jak tuto strategii uplatňovat použitím OS, tvorba teorie potřebných schopností OS, plánování a řízení výstavby OS (tvorba organizace, dislokace, vyzbrojování, vybavování atd.), příprava OS (výcvik vojsk, vzdělávání a př́íprava velitelů a štábů, systém personálního naplnění, systém mobilizace atd.), hodnocení (prověřování) připravenosti OS s důrazem na jejich schopnosti, proces dalšího rozvoje - reakce na měnící se bezpečnostní prostředí, a tím i nové požadavky na schopnosti OS atd.

Na tomto místě je potřebné připomenou důležitý závěr, jež vychází z výše naznačené teorie: schopnosti OS nejsou záležitostí jen jednoho nebo několika dílčích procesů podílejících se na tvorbě schopností OS, ale že tyto schopnosti jsou výsledkem celé množiny dílčích procesů. Úplná schopnost je nedosažitelná. Jde však o to, aby byla co možná nejvyšší svou kvalitou (jakostí) - aby byla možnou optimální schopností v daném okamžiku. Proto by měl být vytvořen systém managementu schopnosti, který by měl za cíl snížit zbytečné ztráty.

Systém managementu schopnosti OS v podmínkách České republiky vůbec neexistuje, nebo pokud existuje, pak je roztříštěn a není chápán v intencích teorie jakosti resp. teorie 
managementu jakosti. Jednou z možností jak celé úsilí tvorby, hodnocení a rozvoje schopností stavět na vědeckých základech je zavést efektivní systém managementu schopnosti OS, a to na příkladu existujícího a permanentně se rozvíjejícího systému managementu jakosti (kvality) v jiných oborech.

\section{Použitá literatura:}

[1] NENADÁL, Jaroslav. Moderní management jakosti: principy, postupy, metody. Vyd. 1. Praha: Management Press, 2008, 377 s. ISBN 978-807-2611-867.

[2] Definice vychází z teorie managementu jakosti J. Nenadála Moderní management jakosti (str. 13), ale autor na rozdíl od ČSN EN ISO 9000:2006 v definici použil termín „stupeň“, což činí z jakosti, resp. schopnosti měřitelnou kategorii.

[3] ČSN EN ISO 9000:2006, Systémy managementu kvality - Základní principy a slovník. Praha: Český normalizační institut, 2006, $64 \mathrm{~s}$.

[4] RMO č. 66/2012, Plánování činnosti a rozvoje v rezortu Ministerstva obrany.

[5] GRASSEOVÁ, M. - DUBEC, R. - ŘEHÁK, D. Analýza podniku v rukou manažera: 33 nejpoužívanějších metod strategického ř́zení. Brno: Computer Press, a. s., 2010, 325 s. ISBN 978-80-251-2621-9.

[6] GRASSEOVÁ, M. a kol. Procesní ř́zení ve veřejném i soukromém sektoru. Brno: Computer Press, 2008, 266 s. ISBN 978-80-251-1987-7.

[7] ČEP, D. - DUBEC, R. Koncepce použití Armády České republiky jako východisko pro tvorbu její struktury v budoucích operacích. In: 7. doktorandská konference Nové př́stupy k zajištění bezpečnosti státu. Brno: UO Brno, 2012, s. 16-23. ISBN 978-80-7231-876-6.

[8] DUBEC, Radek. Rozhodování a plánování v rezortu MO. Vojenské rozhledy, 2010, roč. 19 (51), č. 2, s. 38-47, ISSN 1210-3292.

[9] DUBEC, R. - HRŮZA, P. - SPIŠÁK, J. a kol. Tvorba modulárních struktur úkolových uskupení. Praha: Powerprint s.r.o. 2012, 82 s. ISBN 978-80-87415-54-2.

[10] PIKNER, I. - ZŮNA, P. - SPIŠÁK, J. a kol. Operační koncepce: Př́stupy a postupy. Praha: Powerprint s. r. o., Praha, 2012, 96 s. ISBN 978-80-87415-68-9.

Účinný systém zajišt’ování obrany ČR je vytvářen kombinací politických opatření nejvyšší úrovně řízení státu (legislativy i exekutivy), výstavby Armády České republiky, opatření operační př́ípravy státního území, opatření národního systému reakce na krize pro potřeby řízení obrany státu, výběrovým doplněním OS ČR, mobilizací OS ČR a dalšími opatřeními.

V souladu se závazky a politicko-vojenskými ambicemi ČR je výstavba mírové organizační struktury OS ČR prováděna s cílem maximálního využití jejich schopností a specializace v rámci systému kolektivní obrany členských států NATO včetně účasti OS ČR v operacích společné obrany NATO vysoké intenzity podle článku 5 Severoatlantické smlouvy nebo v obdobných operacích Evropské unie.

I přesto, že ve stávajícím právním prostředí je mobilizace zabezpečena a s její realizací se počítá přri vyhlášení stavu ohrožení státu nebo válečného stavu, systém mobilizace postupně zastarává. Systém jen velmi obtížně reaguje na měnící se hospodářské prostředí a ztrácí schopnost k včasnému převedení OS ČR do válečné organizační struktury. Vzhledem k postupnému úbytku počtu připravených vojáků v záloze OS ČR a minimalizaci množství skladovaného vojenského materiálu pro doplnění útvarů OS ČR válečné organizační struktury, stávající systém je schopen jen v omezené míře připravit a dodat potřebný počet vojáků a vojenského materiálu pro nasazení sil a prostředků do operací ve stanoveném čase.

\section{Koncepce mobilizace ozbrojených sil České republiky. Praha: MO ČR, 2012, www.mocr.army.cz/scripts/file.php?id=140163\&down=yes.}

